Swarthmore College

Works

Fall 2014

\title{
Lesson Plan For Teaching Steve Martin's "Patter For The Floating Lady"
}

\author{
Abhinav Tiku , '18 \\ Peter Schmidt \\ Swarthmore College, pschmid1@swarthmore.edu
}

Follow this and additional works at: https://works.swarthmore.edu/fac-english-lit

Part of the English Language and Literature Commons

Let us know how access to these works benefits you

\section{Recommended Citation}

Abhinav Tiku, '18 and Peter Schmidt. (2014). "Lesson Plan For Teaching Steve Martin's "Patter For The Floating Lady"'. English Literature Faculty Works. DOI: 10.24968/2476-2458.engl.355

https://works.swarthmore.edu/fac-english-lit/355

\section{(c) (1) (8)}

This work is licensed under a Creative Commons Attribution-Noncommercial 4.0 License This work is brought to you for free by Swarthmore College Libraries' Works. It has been accepted for inclusion in English Literature Faculty Works by an authorized administrator of Works. For more information, please contact myworks@swarthmore.edu. 
Abhinav Tiku

Dec. 4, 2014

Before I begin to discuss Steve Martin's work, I would encourage everyone to read the play out loud, either with a friend or by yourself. This is a play and a play is meant to be acted, so enjoy rolling sounds on your tongue and playing around with accents. Doing these actions personally helped me grasp the subtleties in the language.

Now without further ado, let's delve into Steve Martin's Patter for the Floating Lady!

1.] Right off the bat, why is this play so short? I at first hesitated to even call it a play because when I think of a play, I think of a drama with several acts or at least some substantial information in the style of Hamlet or Death of a

Salesmen or Copenhagen.

But after thinking about it, I believe that Steve Martin chose to make this particular play very concise in order to show the raw, 'stripped down to nuts and bolts' relationship between the magician and Angie. The condensed version of the play increases tension, and focuses the complete attention of the audience on a single act, much like a magic show. For one fleeting moment, the entire stage as our undivided attention and because its over so fast, we scramble to recall every little detail that occurred before our eyes.

- Any thoughts?

2.] Because this play is so concise, the story primarily revolves around the characters and the experiences they relive to us, the audience. The only physical action on the stage is the levitating act conducted by the magician.

I think the levitating act, which is the driving element of the plot, is a conduit for channeling emotions that the magician cannot completely express in words. It is through the levitating act, an apparent miracle of magic, that the emotional conflict of the story is brought forth. He himself remarks, "I would like her to know how it feels to have no attachments, yet her freedom is mine" (104). In this way, the miraculous act is a form of communication between the two. But on the other hand, it can be seen as an act of domination by the magician over Angie because he hypnotizes her. When Angie finally levitates by herself without the aid of the magician, this could symbolize her independence and how she has finally broken free from the controlling magician.

Adding more complexity to the magician's motives, he says that his feelings for her are so volatile and repressed that, "She could destroy me by answering the telephone" (104). He claims his reason for performing this trick is, "And I thought if I could give her this, if I could suspend her in space, this would be my exchange for the nights I laid on top of her, she experiencing nothing" (104). In these words, I sense a little guilt about his one-sided relationship with Angie and through this trick, he is attempting to give something back to her: a plea for some redemption perhaps. The nature of the relationship is hard to determine because both Angie and the 
magician seem to genuinely care for each other, and yet push each other apart. - So is he really doing this for Angie or is he simply satisfying his ego as a grand magician?

- Can they only honestly communicate through the mystical? How does magic, or more specifically illusions, contribute to our understanding of their relationship?

3.] Throughout the play, the magician and Angie construct florid metaphors about a whole host of subjects, and the dialogue shifts from monologues to rapid-fire sentences.

- How does this build tension between two as they talk about "biorhythms of the pyramids", "wild rose with an iron stem", and the "tennis shoe"? Though I love the phrases, I sometimes find them confusing to understand. Perhaps this displays the complicated esoteric nature of emotion, specifically love.

- Furthering this point, how does Martin use language to convey feeling and conflict? With a background as a comedian, Martin uses language precisely to elicit certain emotions, mixing words and phrases around to evoke humor; but as a whole, I don't think this play is particularly funny, but is actually witty and acerbic. In this way, I think Martin cleverly creates a dark comedy in the context of a magic act, a performance that is stereotypically exciting whilst having subtle undertones of the occult.

4.] After the assistant arrives and remarks that she is Angie's 'alter-ego' so to speak, how should we interpret what she says compared to what Angie says underneath the trance?

I think that contempt is expressed in both characters' lines, but the assistant is much more explicit and clever in her criticism, such as when she remarks, "And a bulldozer can handle a Tiffany lamp" (110) to the magician (one of my favorite lines in the play).

On the other hand, we can also view the assistant as an 'alter ego' to the magician. In this way, the harsh emotion vented by the assistant toward the magician's behavior is actually self-criticism directed toward the magician. Either way, a surge of emotions suddenly surfaces in the final pages of the play.

- Why is there such contempt directed toward the magician? How has his treatment of Angie affected others' judgement, including our own (I think it's interesting to note that all the information we are given in the play is through the characters, and as the magician states, "everything we say is a lie" (104) -- does this compromise their information or add another dimension to it?)

5.] Finally, what do you guys think of the magician's final lines? I personally found them a little confusing after the assistant and Angie storm off stage, because he seems to casually glaze over the exposition that he just witnessed and move right on with, "And now, is there a women from the audience who would like to assist me?" (113). There seems to be no resolution, no revelation.

- How should we interpret his actions in the last part of the play, and how do they represent his overall character? Does he undergo a personal change or is he still the 
same nonchalant womanizer that he hints he is at the beginning?

On a final note, an interesting reading of this play is the autobiographical version. Steve Martin, at the time he wrote this play, was the middle of formulating a divorce. Does this play perhaps hint at the conflicts of celebrity relationships, balancing being in the spotlight while juggling a private life that everyone knows? An interesting concept that is that the audience is privy to all the personal conflicts in the play in the context of a professional act - we are the tabloids.

-Additionally, how does Martin mix the ideas of comedy and magic? The dangers of magic acts and stand-up comedy is incredibly stressful, because you must maintain control of the situation in order to make the audience laugh or be amazed (in The Prestige, Michael Caine's character famously came up with three rules for every successful magician to follow). Does this impact the way we view the magician in the play? Is he really the prisoner of his own profession? Is Angie collateral damage of his own ambition?

These are just some questions and concepts that arose when I read this play, and after mulling it over in my mind and discussing with my classmates, I have discovered that there are many questions that go unanswered that are equally important. In conclusion this play is packed with information, thematic concepts, and structural choices about celebrities, relationships, and the dangerous implications of stepping on a stage and never coming off of it. 